\title{
Foresight Applications to the Analysis of Global Value Chains
}

\author{
Tatyana Meshkova \\ Director, OECD - HSE Partnership Centre, Institute for Statistical Studies and Economics of \\ Knowledge (ISSEK); and Assistant Professor, School of World Economy, \\ Faculty of World Economy and International Affairs. \\ E-mail: meshkova@hse.ru \\ Evgeny Moiseichev \\ Analyst, ISSEK OECD - HSE Partnership Centre. E-mail: emoiseichev@hse.ru \\ National Research University Higher School of Economics (NRU HSE) \\ Address: 20, Myasnitskaya str., Moscow 101000, Russian Federation
}

\begin{abstract}
$\mathrm{T}$ The objective of this paper is to analyze the scope for improving the empirical and methodological foundation of global value chains (GVCs) research and for making relevant political decisions, primarily through applying Foresight methodology. The authors review the major trends of global value chains' development, specific features of Russia's participation in them, and the necessary steps to increase the quality and efficiency of this participation, in particular in the changing geopolitical context. Special attention was paid to the theoretical, methodological, and empirical aspects of GVC research which are far from adequate (we primarily mean international databases such as TiVA and WIOD developed with the participation of the OECD and the WTO): they need to be supplemented with advanced tools to improve their forecasting potential, as well as their practical and strategic orientation. To this

end, approaches which would make it possible to research the interconnections between global processes and trends with regional and national innovation-based development tendencies become of crucial importance. The application of Foresight methodology may significantly contribute to researching the GVC phenomenon, being a major logical step towards creating advanced research and policy tools to mobilise available resources and coordinate stakeholders' actions to increase global competitiveness. The paper presents several case studies which describe the practical application of Foresight methodology to analyze Russian participation in various GVCs, giving examples of specific product and service groups. The authors conclude that both full-scale Foresight studies and specific components thereof could be applied for the purposes of GVC analysis, strategic planning, and political decision making.
\end{abstract}

Keywords: global value-added chains (GVCs); trade; competition; globalization; innovation; Foresight

DOI: 10.17323/1995-459x.2016.1.69.82

Citation: Meshkova T., Moiseichev E. (2016) Foresight Applications to the Analysis of Global Value Chains. Foresight and STI Governance, vol. 10, no 1, pp. 69-82. DOI: 10.17323/1995-459x.2016.1.69.82 
$\mathrm{B}$ oth developed and developing countries, irrespective of their technological level and income per capita, are involved in global value chains (GVCs), which play a key role in the modern global economy. Global stakeholders have long shown considerable interest in analyzing the structure of global trading in terms of added value and value chains and in identifying current and potential opportunities to embed companies in these chains on country and industry levels. A relatively new phenomenon, GVCs have been the focus of attention for many leading international organizations, including the OECD, UNCTAD, WTO, and G20, with their experts studying the possible positive and negative effects of inclusion in global chains for certain countries and the global economy as a whole. In parallel, the methodological and empirical foundations for studies on GVCs have been continually improved and the heuristic value and reliability of research results have been developed to further justify the ensuing political recommendations elaborated herein.

From a methodological perspective, current GVC studies exhibit the following trends:

- the spread of the so-called industrialist approach, which consists of examining the effects of a chain on the local level of certain industries and clusters;

- looking at the regional and national features of innovation systems which play a decisive role in the transition to the industrialist approach and make it possible to explain the mechanisms underpinning real changes at the level of firms and companies in a specific country through involvement in GVCs;

- increasing the forecasting potential of GVC research to aid in strategic planning and political decision making with regard to involvement in GVCs.

In this paper, we look to combine these three approaches and to analyze the potential to improve the methodological and empirical foundations for GVC research and Russia's long-term strategic planning regarding involvement in GVCs, primarily using elements of the Foresight methodology. We will look at case studies of specific groups of goods and services with an innovative component. Finally, we will briefly analyze the essential features and main trends of GVC development, the key features and indicators of Russia's involvement in GVCs, and the theoretical, empirical, and methodological opportunities and limitations of global chain research.

\section{Global Value Chains as an Element of the Global Economy}

As a modern global economic phenomenon, GVCs clearly demonstrate the pros and cons of intensifying mutual interactions between countries and can serve as a response to the challenges facing them. In a globalized economy, it is not only the final product itself that draws specific attention, from the perspective of employment and development, but also the performance of the companies involved in creating the final product. Developing countries frequently see becoming part of GVCs as opportunities for adding value in a product and strengthening their competitiveness by improving conditions for international business and attracting foreign investment [OECD et al., 2013, 2014].

In general terms, a GVC is a mechanism for increasing value in the process of creating a final product, which might comprise the various technological stages of production and design and marketing [Sturgeon, 2001]. Within each global chain there are:

- forward linkages through exports of primary goods and services, which are then imported back in the form of a finished product (producers of parts and components for complex products with high added value);

- backward linkages, which form around the production and export of finished goods and services and import of primary goods and services (leading producers of finished products) [OECD, 2013].

\section{The Structure of International Cooperation through GVCs}

Over the period 1995-2009, the extent to which many countries were involved in GVCs rose on average by $5-10 \%$ (OECD, 2013) (Fig. 1). Roughly $40 \%$ of total exports by OECD countries is made up of added value created abroad. Since 1995, South Korea, India, and China have most improved their position in GVCs, with their GVC participation index ${ }^{1}$ ranging from $10 \%$ to $20 \%$.

Over the 15-year period under investigation, the average share of services' added value in gross exports by OECD member states and their partners also rose [OECD, WTO, 2013] (Fig. 2). The largest growth in this figure was seen in some of the largest EU economies (Germany, UK, Italy), as well as India and the US, whose added value in services accounts for on average $40-50 \%$ of gross exports. For Russia, this figure remained virtually unchanged at $30 \%$.

The high economic growth rates in several developing countries are generally linked to their increased involvement in GVCs through the use of imported components and materials in the production of goods, including those destined for export. While extensive, in relative terms this growth is however still

\footnotetext{
A country's GVC participation index is calculated as the sum of two indicators: the share of the import component in a country's total exports and the share of exported goods and services used as imported components in other countries exports.
} 
Fig. 1. GVC Participation Index for Major Global Economies in 1995-2009 (\%)

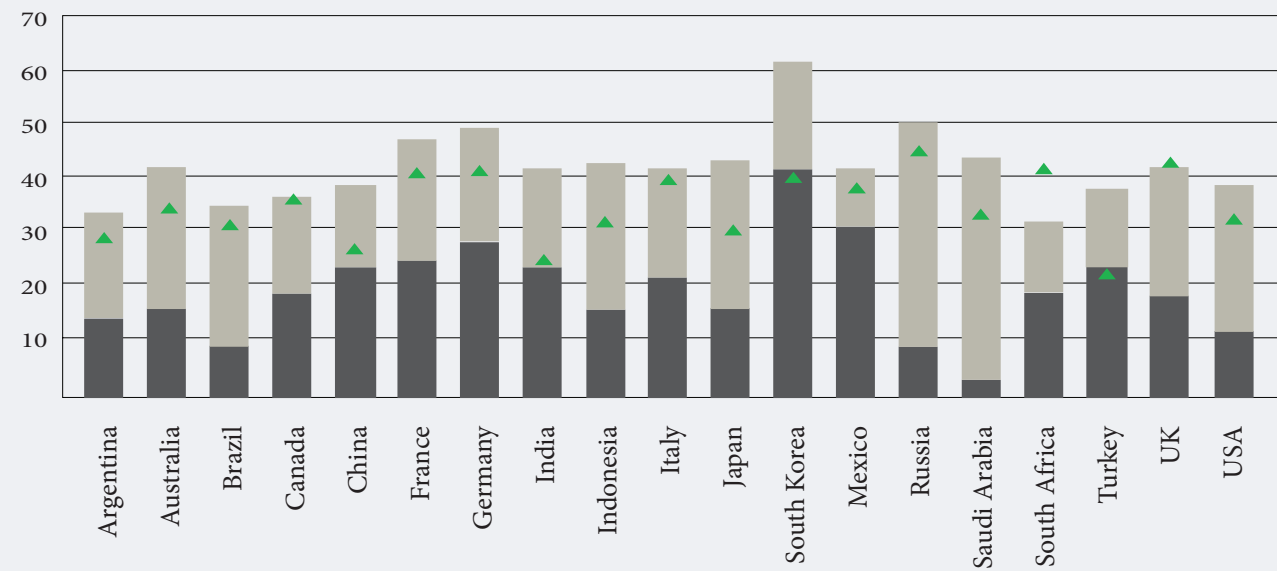

- GVC Participation Index for 1995

- Participation in GVC forward linkages

Participation in GVC backward linkages

Source: [OECD, 2013].

ineffective. According to data from international studies, the largest share of global added value is created in the services sector, not in production.

Fig. 3 shows the different specialties of companies in GVCs according to their profitability. The highest profits are reported in those businesses that are furthest removed in time from the direct assembly of the product, i.e. those involved in the design or after-sales service. The highest-income segments of GVCs, represented by only a narrow group of stakeholders, lay down strategic benchmarks for countries and companies embedding themselves in global chains.

\section{Russia's Position in GVCs}

With a GVC participation index of 51.8, Russia has high global economic integration - 25th place out of 57 [OECD, WTO, 2013]. However, the nature of Russia's GVC participation remains very much geared towards primary materials (see Fig. 1 above).

In terms of participation in backward chains, which form around exports of finished goods and services involving foreign contractors and intermediaries, Russia lags far behind OECD member states [OECD,

\section{Fig. 2. Proportion of Added Value in Services in the Gross Exports of Major Global Economies} in $1995-2009(\%)$

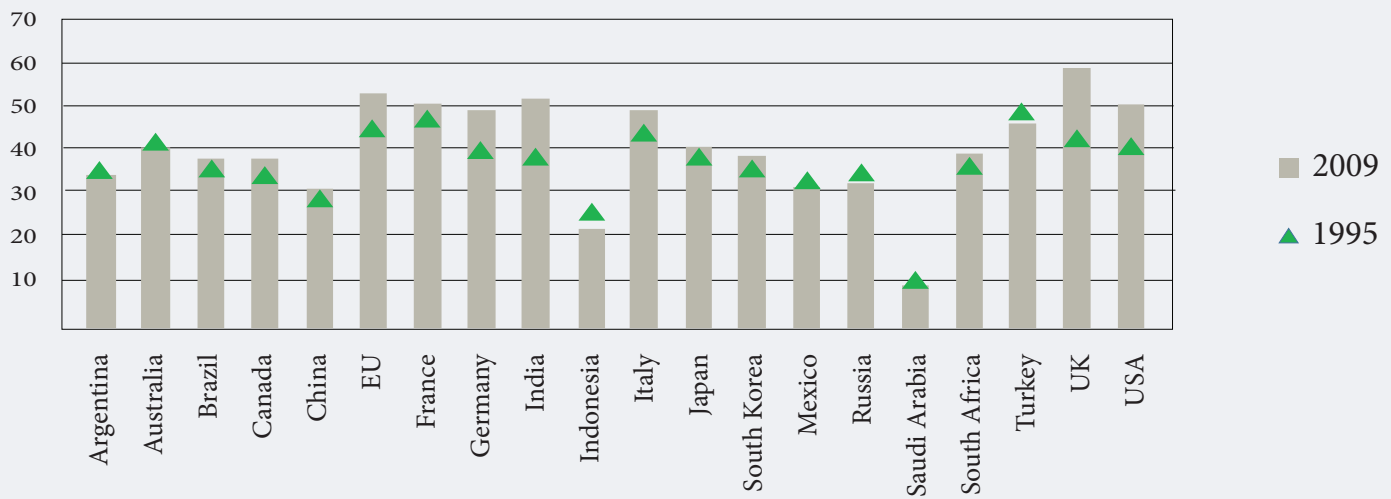

Source: OECD/WTO TiVA database. Available at: http://www.oecd.org/sti/ind/measuringtradeinvalue-addedanoecdwtojointinitiative.htm, accessed 05.011.2015. 


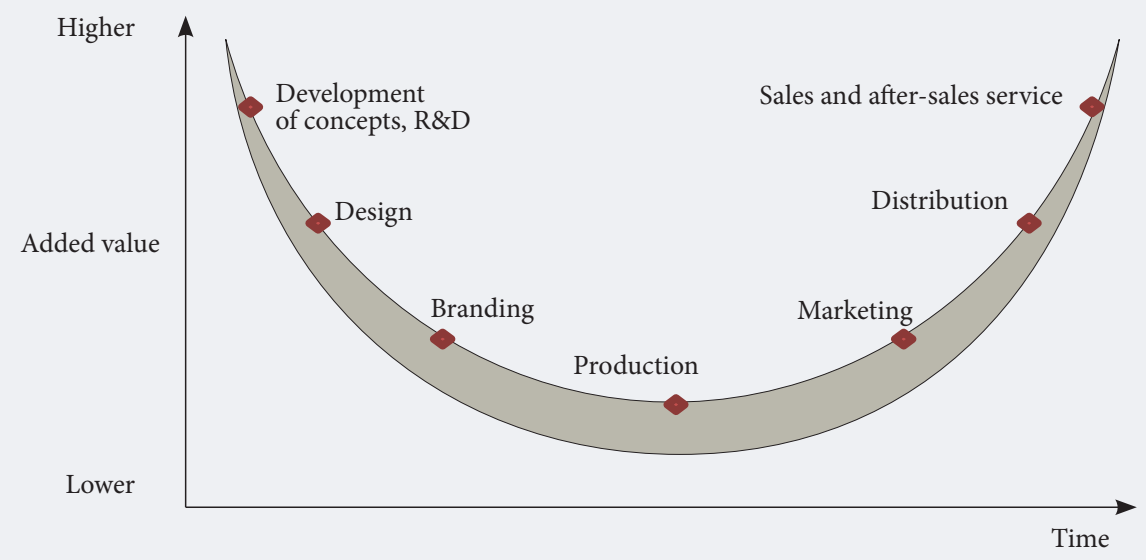

2013] due to the high share of primary goods in its export structure (Fig. 4). Its GVC participation index was 13.7 in 2015, which is the sixth lowest score [OECD, 2015a] after major primary economies such as Indonesia, Brazil, Colombia, Brunei, and Saudi Arabia.

Russia’s participation in GVCs is primarily - in $86 \%$ of cases - through forward linkages, especially in mining, the chemical industry and metallurgy, wholesale and retail trade, and the transport and telecommunications sectors. In other words, other countries use goods exported by Russia primarily as primary materials or components in their own production. ${ }^{2}$ This specialty does not allow for a high share of added value to be created within Russia. Resources exported by Russian companies are returned to the economy in the form of finished foreign goods with a mark-up, which is made higher still by tariff and non-tariff trade restrictions. However, Russia's share of added value in imported goods often exceeds the foreign component.

Thus, the current format of Russias participation in GVCs does not allow it to achieve any of the potential long-term benefits. At the same time, the complex geopolitical climate and pessimistic forecasts regarding future economic growth in Russia should not hold back efforts to take advantage of Russia's competitive advantages, minimize possible risks, and maximize the positive effects of participation in global chains. ${ }^{3}$ This work should in particular consist of identifying opportunities in sectors where Russia has a chance of occupying leading positions in backward linkages in the foreseeable future.

\section{GVCs as an Object of Study and Strategic Planning}

Growth in the political and economic value of GVCs has attracted the attention of experts and decision makers. At the same time, the theoretical, methodological, and empirical resources for studying global chains have expanded. In his proposal for consolidation and further transformation of the OECD [Gurría, 2015], the OECD Secretary General Angel Gurría highlighted the heuristic value of research in this field and noted that analysis of the added value of gross exports and GVCs in fact made it possible to 'decode the trade genome, and so this work needs to be continued, applying the results of research in real trade negotiations.

\section{The Theoretical and Empirical Basis for Studies on GVCs}

The notion of a valued added chain emerged in the 1960s-1970s. There are two main schools of thought on the study of value chains - internationalism and industrialism [Morrison et al., 2008].

The first school is made up of North American researchers, primarily headed by the director of the Center on Globalization, Governance and Competitiveness at Duke University, Garry Gereffi [Gereffi, 1999; Gereffi, Kaplinsky, 2001; Kaplinsky, 2004]; several European academics including a leading specialist at the Institute of Development Studies at the University of Sussex, Rafael Kaplinsky [Kaplinsky, 2000]; a researcher at the Danish Institute for International Studies, Peter Gibbon [Gibbon, 2001, 2003]; and others. The industrialist school is made up of specialists based at the Institute of Development Studies at the University of Sussex [Humphrey et al., 2000; Humphrey, Schmitz, 2002].

\footnotetext{
2 The proportion of oil and gas in Russian exports is as high as 70\% [Federal Customs Service, 2015].

3 For more on the risks and benefits of participating in GVCs, see: [Meshkova, Moiseichev, 2015].
} 


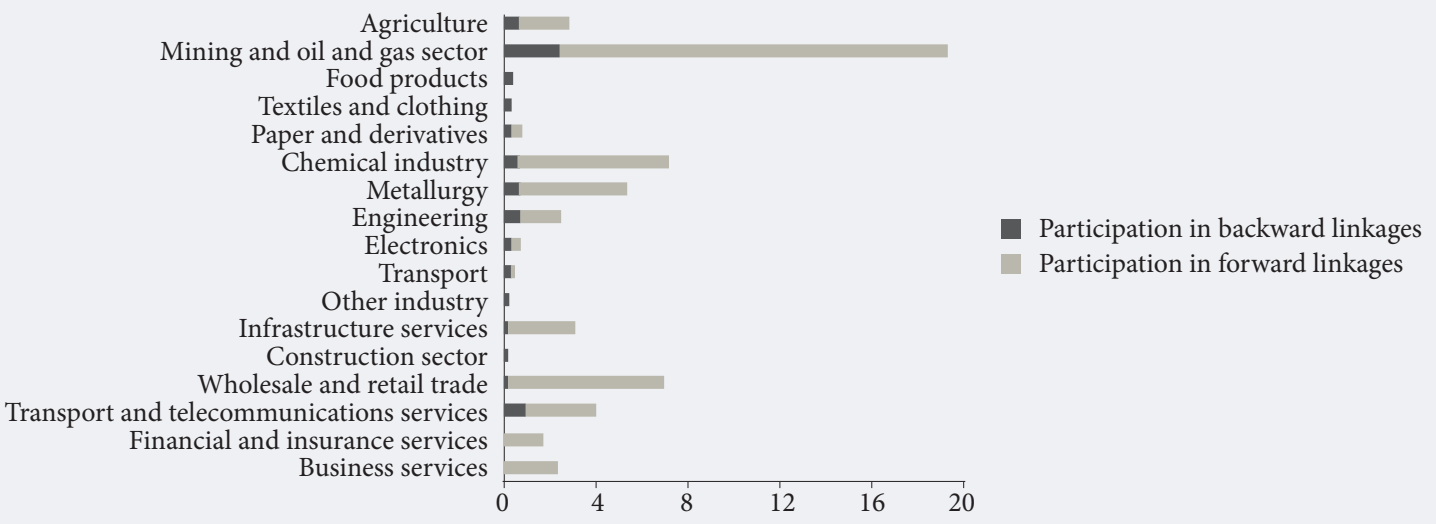

Source: [OECD, 2010].

'Internationalists' rely predominantly on macro-level studies - both in terms of the units of analysis and the scope of the formulated recommendations. 'Industralists' focus on more the local, micro-level experience of certain sectors and clusters. The distinction remains relative, however; these schools actually complement one another, for instance in the form of joint publications by their members [Gereffi et al., 2001, 2005].

The empirical basis for GVC research comes in the form of two international databases - TiVA (Trade in Value-Added) and WIOD (World Input-Output Database). The first was developed jointly by the OECD and WTO [OECD, WTO, 2013] and allows researchers to have a new insight into modern international trade, moving away from an analysis of export-import flows of goods and services to a more comprehensive study of the GVCs underpinning these flows. A second version of the TiVA database is now live, dating from May 2013, which contains both traditional indicators of foreign economic activity and a number of new indicators which describe national economies in terms of their participation in GVCs. TiVA holds information on 57 countries, including all the OECD member states, as well as Brazil, China, India, Indonesia, Russia, and South Africa. TiVA covers the years 1995-2009 and encompasses 18 sectors.

Forecasts of countries' GVC participation use the WIOD database, developed by researchers at Groningen University [Timmer et al., 2012]. ${ }^{4}$ WIOD contains information on the $27 \mathrm{EU}$ member states as well as 13 major trading partners of the EU for 1995-2009. The database includes national and international 'input-output' tables, as well as tables showing resources and how they are used.

While a statistical analysis of trade based on the value added structure and global value chains is a productive endeavour, it is not fully reliable when it comes to decision making in trade or industrial policy, for example. This is because is not sufficiently detailed and the data are not current. In addition, the global nature of GVCs means that databases must offer complete global coverage. However, at the moment the databases often lack information about entire regions. For example, of all the Commonwealth of Independent States (CIS) / Eurasian Economic Union countries, only Russia is listed in the OECDWTO TiVA databases, and these chains are merely extrapolations of a 1995 input-output model [Novaya Gazeta, 2010]. Such methodological limitations cannot be overstated, given how much internal and external economic conditions have changed since 1995.

\section{GVC Research: Opportunities and Limitations}

From a methodological perspective, we argue that the best approach to forecasting changes in GVC structure and to making policy recommendations about how to integrate more companies into GVCs is that advocated by Rafael Kaplinsky [Kaplinsky, 2004], combined with elements of the Foresight methodology using the notion of dynamic economic rent. Kaplinsky takes up this notion using the production, export, and marketing of product groups such as vegetables, fresh and tinned fruits, footwear, and vehicle parts as examples. The focus of his analysis was the structure of the product creation chain, the main source of economic rent in the past, present and future, and the most important consequences for production activity.

\footnotetext{
${ }^{4}$ See also: http://www.wiod.org/new_site/data.htm, accessed 28/11/2014.

5 Accessible at: http://www.gks.ru/bgd/free/B99_10/IssWWW.exe/Stg/d000/i000370r.htm, accessed 23/07/2015.
} 
The model entails an element of forecasting as a future projection of the structure of sources of economic rent, the methodological justification for which, however, remains unclear. One of the shortcomings of this model is that the analysis is restricted to specific groups of products and does not include services (financial, transport, logistical, etc.), while it is precisely this latter sector that allows economic stakeholders to most effectively embed in backward value chains. Contrary to the linear formation of added value presented in the model, the interactions between GVC links generally take on a networked character [Lundvall et al., 2015], which is especially evident in the services sector. Studies of GVCs through the prism of specific case studies are not always supported by reliable empirical data and are often criticized for being subjective [Malerba, Nelson, 2011; Milberg, Winkler, 2011; Wood, 2001]. At the same time, case studies, at least in the absence of actual input-output model data, allow researchers to operationalize results to the greatest extent possible.

Critics of the methodology for GVC research among researchers of innovation systems and innovation economies [Ernst, Kim, 2002; Pietrobelli, Rabellotti, 2011] argue that such a methodology underestimates the local context of clusters analyzed and the specifics of national institutions that create the conditions for improving companies' positions in GVCs. Advocates of this approach in turn note that their opponents ignore the nature of governance and interactions between economic agents, the distribution of power, and the influence of economic agents on each other within a specific innovation system [Gereffi et al., 2005; Sturgeon, 2001]. Currently, several researchers [Lundvall et al., 2015] are trying to overcome this schism, proposing to bring together the various scientific schools into a fundamentally new approach one devoid of the shortcomings of existing theories and proposing a more complete understanding of GVCs. The existing methodology to study GVCs needs to be supplemented with modern instruments offering greater forecasting potential and practical and strategic focus. Approaches which combine the analysis of interactions of global processes and innovative development trends with national institutional specifics could play a key role in achieving these aims.

Defining the position and role of companies in GVCs has a great deal in common with the aims and objectives of science and technology Foresight. Thus, the concept of a value-added chain was used when developing a corresponding long-term Forecast for Russia and analyzing the strategies of key economic sectors to structure each sector, identify possible points of technological growth, organize new businesses, and reveal appropriate centres of excellence [Chulok, 2009]. The National Technology Initiative (NTI) is now developing a mechanism to establish fundamentally new markets and create conditions for Russia to be a global technological leader by $2035 .^{6}$ To solve this problem, Foresight methodology was used to appraise the challenges that the country will face in the coming 10-15 years and the leading solutions to guarantee national security, quality of life, and the development of next-generation technological industries. The NTI is primarily geared towards seeking out new markets where Russia has potential competitive advantages and, besides markets and technologies, also encompasses the corresponding institutions and infrastructure.

Use of Foresight methodology is not only an important step towards achieving these aims, but also a valuable resource when studying GVCs as an integral element of modern state policy. It consists of mobilizing available resources and coordinating the efforts of stakeholders to increase Russia's global competitiveness.

\section{A Foresight Study of Russia's Actual and Potential Participation in GVCs}

Drawing on the international experience of GVC studies, we applied elements of the Foresight methodology to a sectoral analysis of two product groups included in Kaplinsky's model — fresh fruit and vegetables, and vehicle parts. We added several other categories to the analysis such as 'mobile telephones', 'air travel (transport services)', and 'electronic payment systems (financial services)'. Ultimately, this choice was not down to these groups of products and services belonging to priority areas in science and technology [Gokhberg, 2014]. The new markets for which 'road maps' are now being created within the NTI (AeroNet, AutoNet, FoodNet, and others) partly overlap the aforementioned categories. For these, we identified the actual and future structures of GVCs in the corresponding industries and determined Russia's current and possible position in them.

The Foresight analytical tool kit allows us to identify factors behind changes in the structure of GVCs, sources of value and their distribution across individual links in the chain, and Russia's opportunities to gain more profitable positions over the next 10-15 years (up to 2025). We examined global factors such as the development of GVCs in specific industries (predominantly those of an objective nature, i.e. independent of particular political decisions regarding the process of globalization and evolution of production) and prospects of participating in these GVCs, the main challenges and threats facing industry GVCs, opportunities to embed linkages into those GVCs allowing for maximal material and associated (political, strategic, social, etc.) gains, and the role of research and development (R\&D) in areas allowing for the application of technological, marketing, and administrative innovations developed to embed in GVCs and obtain the greatest possible return from participation in them.

\footnotetext{
${ }^{6}$ For more information, see the website of the Agency for Strategic Initiatives: http://asi.ru/nti/, accessed 09.03.2015.
} 
Kaplinsky's model was supplemented with a set of policy (primarily state) measures to integrate Russia more deeply and productively in GVCs. Following international recommendations [OECD et al., 2013; 2014], we identified so-called horizontal and industry (sectoral) measures for each group of products and services. International experience of countries' participation in GVCs, including through collaboration between OECD member states, several international organizations and their partners, showed the fundamental importance of a range of horizontal political measures to a successful strategy to embed in GVCs: development of infrastructure and communications, support for the business environment, the financial sphere, science and innovation, education and employment, macroeconomic stability, and others.

A targeted industry-specific (sectoral) policy, while not sufficient in itself, is an important addition to the measures listed above. A sectoral approach (for instance, the use of tariff and other trade restrictions, subsidies, export regulations, restrictions on foreign investment, etc.) could at best provide positive changes in a specific industry (most frequently in a group of companies). However, such an approach could not produce a positive cumulative effect for the economy overall. 'Horizontal' measures including in the science, technology and innovation sphere, are in line with the approach advocated by the innovation economics school [Cooke, 2001; Etzkowitz, Leydesdorff, 2000; Lundvall et al., 2015; Pietrobelli, Rabellotti, 2011] to identify the relationship between the nature of participation in GVCs and the specifics of national innovation systems.

\section{Agriculture: Fresh Fruit and Vegetables}

\section{Description and Russia's Current Position in the Chain}

GVCs in the production and sale of fresh fruit and vegetables are made up of the following links: seedfarming, cultivation, processing and packaging of crops, export, and retail trade. In theory, Russia is involved in each of these, occupying other positions to a lesser extent in export and seed-farming. At the same time, seed-farming is now the most profitable segment of the entire chain: the size of the global seed market for fruit and vegetables is over 6 billion US dollars. With current annual growth at 28\%, by 2018 it could reach 13 billion dollars [Ken Research, 2014].

\section{Global Trends}

The key global trends in agriculture overall and in fresh fruit and vegetables cultivation in particular include: increasing competition in seed-farming, development of genetic engineering, expanded international cooperation in food security, overcoming the problems of starvation and access to food in less developed countries, and growing demand for environmentally friendly, natural farm produce in the more economically developed countries.

\section{Challenges and Threats}

Russia is considered to be a country with a traditionally developed agricultural sector but one that makes very little use of its GVC potential in terms of growing fresh fruit and vegetables. After the collapse of the USSR, the country played virtually no role in the selection and export of seeds and development of new products, despite the critical value of this sector from a food security perspective. The shortage (strictly speaking) of free land for experimental fields and inadequate support for domestic R\&D in seed-farming hamper effective involvement in GVCs in Russia.

\section{Opportunities}

Attaining more profitable positions in 'agrarian' GVCs is a particularly pressing challenge for Russia in light of the country's recent policy of import substitution and development of the domestic agricultural produce market. The 'counter-sanction' import restrictions introduced in the summer of 2014 served as a catalyst to transform the GVCs in which Russia was involved. Currently, Russian retailers are moving away from EU member states and the US in favour of Russian producers or suppliers from Latin America, Turkey, Iran, China, and Vietnam; this trend has a direct impact on the future prospects of the industry and national economy overall. The practical aim of the government's policy should be to ensure far-reaching access to sales channels for as large a number of domestic and foreign producers as possible and to recover from the damage caused by the departure of Western partners from the market while maintaining high quality standards in agriculture and ensuring that produce is affordable for the population. In the long-term, achieving these aims requires a healthy and equitable distribution of economic rent across all GVC participants, including small- and medium-sized producers alongside larger players.

One of the most pressing areas of R\&D in agriculture today is the development of genetically modified produce and fertilizers which meet environmental and food security standards. The main opportunity here for Russia lies in developing export seed-farming and import substitution through revitalizing the scientific and technological foundations underpinning the industry. 


\section{Regulatory Instruments}

From a strategic perspective, Russian industrial policy in the fresh fruit and vegetables segment should involve support for seed-farming companies. Russia needs to revitalize the scientific and human resources lost over the early 1990s, improve the business climate, and attract investment alongside targeted regulation of the industry to make it easier for seed-farming companies to access external and internal markets.

\section{Prospects of Improving Russia's Position}

One of the most important conditions for Russia to be able to embed itself into agricultural GVCs is having strong seed-farming and retail links. The remaining links, while not guaranteeing the same high yields, nevertheless also deserve appropriate support to provide a complete production cycle.

\section{Air Travel}

\section{Description and Russia's Current Position in the Chain}

Air travel is linked into an entire network of GVCs encompassing information and communication technology (ICT) infrastructure, retail (including travel agents), airlines, aircraft construction, and landbased infrastructure. Airports are the most influential players in this GVC, something long acknowledged by researchers of industry-specific markets [DiLorenzo, 1996; Vasigh et al., 2013, 2014; Zhang, Round, 2011]. Russian aviation, which is embedded in all links of the chain, is held back from integrating into global logistics by the underdeveloped market mechanisms for the industry's regulation due to high air travel tariffs and the fact that Russia has not adopted international logistical standards for electronic registration and handling of freight.

\section{Global Trends}

Aircraft construction and air travel are extremely important in terms of economic development (in particular in the context of logistical systems and science-intensive sectors) and act as technology donors, enabling a multiplier effect on a national level. Aviation GVCs are characterized by their scale and complexity. The global trends in this area include:

- increasing international competition;

- growth in passenger and freight numbers;

- developing inter-state collaboration in the form of air travel alliances;

- rapid modernization of aircraft fleets and digitalization of air travel registration and tracking;

- an increase in the proportion of regional and local journeys in most countries.

\section{Challenges and Threats}

The strong correlation between ticket prices and fuel prices, high price elasticity of demand, and the shortage of personnel as a consequence of the high cost of pilot training are among the challenges facing Russian GVC participants in the field of air travel. All these factors are fraught with losses for all participants in the chain. For example, in 2015 the Central Bank of the Russian Federation transitioned to a floating exchange rate for the rouble, which led to the costs of leasing for carriers exceeding the admissible limit and led to numerous bankruptcies [Kukushkin, 2015; RZD-Partner, 2015].

The domestic air travel market in Russia has been experiencing considerable difficulties in ensuring a sufficient level of profitability [Belousov, 2013; Kukushkin, 2015; Bessarabova, Sologub, 2015]. In the interests of connecting Russia's vast expanse of territory, the government had to subsidize unprofitable routes to distant and isolated communities [Belousov, 2014]. The international market guarantees high profits with higher competition.

\section{Opportunities}

The prospects for Russia being more involved in aviation GVCs are linked to the realization of competitive advantages in freight transportation and the expansion of the regional and local flights market. Both niches are still poorly developed compared with foreign markets, although they are gradually expanding [RZD-Partner, 2015; RBC, 2015; RBC.research, 2015]. The role of R\&D in this area could be in optimizing electronic ticket reservation equipment, introducing a unified standard for online freight registration, personalizing services, and in modernizing aircraft fleet. Ultimately, innovations aimed at cutting costs and increasing the profitability of airlines and the industry overall are all important. ${ }^{7}$

\footnotetext{
An example might be consultancy and project services offered by the Innovation Centre for Civil Aviation to realize the transit potential of Russia's airspace, reduce the financial burden on airlines, improve industry legislation, develop domestic freight, regional and local air travel, optimize the mechanisms and infrastructure to ensure that civilian aircraft are suitable for use in summer, and introduce an e-Freight international standard for electronic registration and handling of freight (available at: http:// www.c-ca.ru/ru/company.html, accessed 29.07.2015).
} 


\section{Regulatory Instruments}

The prospects of domestic players in the air travel market (in particular, the carriers themselves) remain hazy in the medium-term. Developments over the next five to ten years will be threatened by the volatility of the rouble exchange rate and geopolitical instability, meaning that the need for state support will remain.

The 'Plan of Priority Measures to Ensure Stable Economic Development and Social Stability in 2015' approved by the Russian Government sets out measures to support the air travel market, among other things. In particular, there are plans to gradually reduce VAT on domestic flights to zero, increase subsidies for carriers to maintain the network of routes to distant and difficult-to-access communities, expand state support to lease aircraft for regional travel, and jointly finance domestic air travel not only at the expense of regions of the Russian Federation, but also all links of the transport infrastructure airports, airlines, investors, etc.

The efficiency of land-based infrastructure can be guaranteed by traditional anti-monopoly policy measures. For example, this may be by approving investment demands on leaseholders, operators and owners of bulk fuel installations and infrastructure monopolies, developing competitive procedures to transfer the land-based production facilities of airports to operators and investors, adopting a state (tariff) regulation system for aircraft storage and refueling services linked to the implementation of an investment programme, and excise-free imports of aviation fuel for five years.

The aircraft construction industry plays a very important role in the development of GVCs. Russia has the potential to keep a vertically integrated production model, heavily dependent on exports, and therefore on political and economic shocks - restricted access to credit resources, technological sanctions, etc. The conditions are such that implementing an import substitution policy by developing domestic scientific and production facilities (especially for critical technologies) and diversifying external partners becomes a matter of national security. In the long-term, such measures will partly make it possible to move over to the use of domestic aircraft, protecting leaseholders from foreign currency shocks.

The expansion of the air travel market will be helped by the development of transport integrators and services using domestic ICT innovations, including computer systems to optimize the aircraft fleet and routes, electronic ticket reservation mechanisms, selecting the most profitable tariffs, introducing a unified online freight registration standard, etc. The development of human capital, including subsidizing pilot re-training, training personnel for civil aviation based on forecasts of passenger and freight turnover, and improving statistical analysis of data in line with the recommendations of the International Civil Aviation Organization (ICAO) and experiences of countries with lowest accident rates will all be of critical importance. Important industry-specific measures should include the introduction of the international e-Freight and e-Cargo standards in the electronic registration and handling of freight and harmonization of these mechanisms across different forms of transport.

Finally, it would be sensible to further integrate Russia into international transport institutions, including the International Transport Forum (ITF), OECD-ITF Joint Transport Research Centre (JTRC), EURussia Transport Dialogue, Northern Dimension Partnership on Transportation and Logistics (NDPTL), ICAO, and others.

\section{Prospects of Improving Russia's Position}

To gain as much as possible from involvement in aviation GVCs, Russia needs to create a network of modern airports, increase competitiveness in aircraft construction, and develop the regional and local flights market.

\section{Mobile Telephones and Smartphones}

\section{Description and Russia's Current Position in the Chain}

The main GVC links in the field of mobile telephones and smartphones are product R\&D, production, packaging, export, and retail trade. Russia's involvement in these links is almost non-existent. The production link in this GVC is largely located in East Asia while the science-intensive links are controlled by companies in Western countries and Japan. In isolated cases, domestic players act as GVC coordinators (the most striking example of which is the company Yota). However, the overwhelming majority of domestic actors buy in standard devices from Asia, focusing more on marketing and sales, while a small group of retailers sell goods purchased abroad.

\section{Global Trends}

Development of this market is tied in with the growing complexity of production and increasing international competition, the emergence of new players on the market, intensifying international cooperation, and the transfer of production facilities to South East Asian countries. The never-ending changes in users' demands and preferences (for example, the spike in the popularity of smartphones), rapid obsolescence of products in the industry, and the transformation of final markets in the wake of technological and behavioural dynamics continue to be perceptible trends. 


\section{Challenges and Threats}

The influence of Russian GVC participants in the field of mobile telephones and smartphones is almost entirely restricted to CIS countries. Domestic companies are primarily occupied with re-selling foreign products on the domestic market with a corresponding mark-up. Against the global backdrop, they are of little importance.

One of the main challenges is the rapid technological improvement of devices combined with their fast obsolescence. In parallel, countries which have key (or blocking) technologies are becoming more isolated. The status of undisputed technological leaders allows them to further improve their products and innovate. This means that countries which find themselves on the technological periphery for various reasons (including patent restrictions, shortage of skilled workers, insufficient scientific potential, lack of corresponding infrastructure, technological sanctions, etc.) are deprived of opportunities in this sector.

\section{Opportunities}

Russian participants of the mobile telephone and smartphone market have some of the best starting positions in design and R\&D. In this particular area, they could compete with middle and upper price bracket foreign manufacturers for consumers in CIS countries, Eastern Europe, and the former Soviet Union. Mobile communications technologies will undergo dynamic changes over the next few decades but will likely remain profitable. Hence, domestic companies now need to conquer new markets and occupy strategically profitable positions.

\section{Regulatory Instruments}

Since the bulk of the profits in these GVCs are generated by the R\&D and marketing links, robust personnel as well as education, science, technology and innovation policies are required in order to realize existing opportunities. An important element of this could be to improve the image of engineering disciplines and encourage those studying ICT and design. It would be advisable for the government to offer support to core higher education institutions, finance additional publicly-funded positions, introduce effective mechanisms for academic mobility among students and academics, and attract recognized foreign specialists from countries with the latest technologies and leading developments in ICT.

The government also needs to focus its efforts on specific science and technology capacities. In this context, the greatest value comes from the skillsets of Russian developers in the computer-aided design of components and new technologies to work with multimedia information [Gokhberg, 2014]. Such a broad approach to the development of ICT requires priority support for innovative industrial clusters through innovation policy [OECD, 2015b]. Special and industry-specific measures are redundant here as the dynamics of the industry of mobile communications devices, as one area of the comprehensive development of a digital economy, will over time reduce the technological gap between domestic and foreign developers.

\section{Prospects of Improving Russia's Position}

The high profitability of certain GVC links in the field of mobile communications will sooner or later start to decline as access to existing technologies expands. A key role in this process will be played by so-called disruptive innovations, which create new markets and shake up existing ones. As a result, any market forecast today cannot be considered entirely reliable. This does not however lessen the value of long-term science and technology forecasting, including the use of the Foresight methodology. In view of Russia's existing scientific and technological capacities and high quality human capital, the country has the capability to expand its presence in the science-intensive and profitable links of corresponding GVCs - R\&D, design, and sales.

\section{Vehicle Parts}

\section{Description and Russia's Current Position in the Chain}

The main GVC links in the vehicle parts trade are design, production, and sales. Production is a modular system, or platform, comprising design, manufacture, and assembly. Businesses performing the most technologically complex operations (pressing, manufacturing engines and gear boxes, electronic components, etc.) are situated closest to the central offices of the companies, while the assembly plants are closest to the sales markets. Assembly, together with design, amasses the greatest proportion of added value, while the contribution of industrial production to added value is minimal. In Russia, the design segment is virtually non-existent, while the remainder is developing within global car manufacturers operating in the country.

\section{Global Trends}

On a global map of the vehicle manufacturing industry, the design and sales segments are controlled by a few international corporations with numerous production facilities in developing countries. The oligopolistic trend of this market is growing while the number of independent parts manufacturers 
shrinking. They are gradually becoming dependent on the auto-giants, setting up joint ventures, entering strategic alliances, or end up being absorbed like certain local manufacturers.

A similar situation is now observed in Russia: domestic manufacturers are being drawn into international cooperation, embedding themselves in the GVCs of larger and more successful global players and losing their autonomy. According to leading foreign experts, the vehicle parts manufacturing industry still offers no prospects when it comes to improving a company's standing in the corresponding GVCs [Gereffi et al., 2005; Humphrey, Schmitz, 2002; Kaplinsky, 2004].

\section{Challenges and Threats}

In the current conditions and the foreseeable future, not a single Russian car manufacturer will succeed, all things being equal, in building a globally competitive value-added chain. Without this, the Russian auto industry could be doomed to lagging behind and playing a game of catch-up at the same time as seeing further declines in profitability. Domestic manufacturers have the necessary skills in parts manufacturing, but lag behind foreign companies in design and sales, which require a higher level of intellectual and innovative potential. Russia’s labour resources are more expensive and less qualified than those in the Asia Pacific region.

International industrial cooperation between the Russian auto industry and stronger foreign partners in the form of joint assembly facilities only further reinforce the backwardness of the industry, while the most profitable links - design and sales - are left to the global giants which amass the bulk of the income. This is characteristic of the situation in many developing countries. Experts see a way out of this situation in reducing state support for national GVC participants and investing in other, more economically promising industries [Humphrey et al., 2000]. On the whole, such a recommendation is fair for Russia too, but it does not take into account the strategic importance of the automotive industry to the country's economy and the importance of the scientific, technological and production potential accumulated in the industry. Therefore, a subsidy policy remains the only sensible course of action for the time being.

\section{Opportunities}

In the short- and medium-term, the development of vehicle parts manufacturing in Russia will be largely inert with gradual increases in foreign presence on the market and a reduction in economic rent. In the 40-50 year horizon, this trajectory will reach a dead-end. At the same time, by 2050 or earlier, opportunities will open up for the Russian auto industry that are linked to the spread of cars, alternative, modern, electric cars, cars running on fuel cells, compressed air, hydrogen, etc. The role of R\&D could also be important in the development of 'smart' cities, which involve a move away from personal vehicles in favour of efficient, fast, environmentally-friendly, and cheap public transport in global megalopolises, including contemporary policy tools and business models such as car-sharing [HSE, 2016].

\section{Regulatory Instruments}

The demand of city-dwellers for personal vehicles will most likely fall considerably by the middle of this century. This scenario could be extremely advantageous to Russia, as domestic manufacturers have done far more groundwork in the sphere of freight and public transport. Overall, given the country's current situation in GVCs, labour and employment regulation is extremely important in the vehicle construction industry. Professional association rules and expanded worker rights could lead to additional costs for manufacturers and make it harder to compete on price for consumers.

The government's main efforts should be directed at supporting technological development and innovation, long-term forecasting, 'predicting' the future of the vehicle construction industry using the Foresight methodology, training personnel, and investing in technology to take over from today's vehicles. A special example of this could be the development of public transport systems in major cities and encouraging people to move away from using personal vehicles.

\section{Prospects of Improving Russia's Position}

The indefinitely distant prospects do not detract from the accurate assessments of the current position of Russia's vehicle parts industry as described in [Humphrey et al., 2000], which note the small chances of embedding into global GVCs. Subsidies to the industry will only grow in the future and human resources will start to decline. Only a radical transformation of the market and consumer preferences will be able to overcome this situation, which are hardly likely in the foreseeable future.

\section{Electronic Payment Systems}

\section{Description and Russia's Current Position in the Chain}

GVCs in the financial services sphere cannot be described as a usual chain of links. Unlike more traditional manufacturing industries, financial services are organized more according to network principles, and the activities of certain links are fully automated. An example of this networked distribution of 
tasks between participants in the banking sector chain is the specialist 'UniCredit' centres located in different countries. ${ }^{8}$ For example, bank branches in Ireland specialize in asset management, in Germany in investment banking services, in Austria in mortgage lending, and in credit card services in Turkey [Backer et al., 2014].

The domestic financial services market formed relatively recently and has huge potential due to its relative diversity in terms of the range of services on offer, comparable with any developed foreign market. Alongside non-residents, domestic players are also present on the market with their numbers continually growing. One perceptible market trend is also the growth in the share of cashless payments as a consequence of the rapid development of Internet banking, electronic money, and the non-bank credit institutions segment.

\section{Global Trends}

Electronic payment systems are one of the fastest growing industries in the financial sector. The largest among these are Visa, MasterCard, American Express, DinersClub, JCB (Japan), and UnionPay (China). UnionPay has shown the highest growth trends: since 2010 it has been the leader in the number of cards issued, but still occupies only a tiny share of the Russian market. The global development of the electronic payment systems sector is characterized by growing competition, expansion of the range and coverage of non-bank financial services, and e-commerce.

\section{Challenges and Threats}

The dependence of the banking sector on foreign players, the emergence on the domestic market of new foreign payment operators, and the low level of competitiveness of domestic financial services are among the risks and threats to the development of electronic payment systems in Russia. The political climate also has an impact on the state of the sector. Some of the largest Russian banks have been affected by foreign sanctions: Gazprombank, Sberbank, VTB Bank, Bank of Moscow, Rosselkhoz, and Vnesheconombank [US Department of State, 2014; EU Newsroom, 2015]. The imposed restrictions prevent Russia from effectively participating in the corresponding GVCs.

\section{Opportunities}

The introduction of sanctions against a number of players in the Russian banking sector served as further encouragement for the creation of a national payment card system (NPCS) to process transactions within Russia using international cards. The NPCS clearing centre was opened on March 31, 2015. The development of the e-commerce market and the NPCS was a pledge of Russia's effective participation in financial services GVCs, as this affords Russia greater independence in its national economy, and in the long-term allows it to set up an international payment system like the China's UnionPay, in part through integration with CIS and Eurasian Economic Union countries.

\section{Regulatory Instruments}

Consolidation of Russia's position in these GVCs could be aided by expanding the scale and increasing the efficiency of activities and raising the reputation of the NPCS to a level comparable with equivalent foreign and international payment systems; optimizing the Russian bank state oversight system (primarily through the Central Bank); and continuing with a policy to reinvigorate the banking sector and improve core legislation, including through the adoption of international standards. In the education sector, we need to raise the financial literacy of the Russian population.

Industry-specific recommendations could include developing the regulatory and legal framework, human capital, and R\&D in ICT to support the industry's current activities and develop optimal mechanisms for transactions and data protection. The stability of Russia's position will in many ways depend on the effectiveness of its collaboration with strategic partners through new international initiatives in the financial sphere, such as the New Development Bank BRICS (NDB BRICS) and Asian Infrastructure Investment Bank (AIIB) set up by the Shanghai Cooperation Organization Development Bank (SCO Development Bank).

\section{Prospects of Improving Russia's Position}

Protecting the domestic financial market is critically important to Russia by creating competitive domestic equivalents to foreign electronic payment systems and taking up influential positions in new international financial organizations.

\section{Conclusion}

GVCs are now starting to become both a more widespread mechanism in the global economy and an object of research and strategic planning on both national and international levels. Although existing

8 Available at: https://www.unicreditgroup.eu/en.html, accessed 21.07.2015. 
approaches to GVC research in many ways complement one another, the theoretical foundations are not without fault. Core studies are now being worked on predominantly by scholars taking an innovation economy approach. The empirical and methodological foundations for studies on GVCs are improving and the reliability of research findings and their forecasting value increasing. In addition, the rationale for policy recommendations from research is strengthening and opportunities for strategic planning are expanding.

Results of tests using a Foresight methodology confirm the effectiveness of these tools in terms of studying GVCs both when using it as an integrated methodology and when using just certain elements of Foresight. In particular, we are talking about identifying global trends affecting the development of GVCs, identifying risks, threats, and vulnerabilities of chains in which Russia is involved, analyzing 'weak signals' and 'joker' events, and examining the stability of existing GVCs and carrying out SWOT analyses. Lists of cutting-edge R\&D areas and descriptions of potential results can be used to assess the potential of new GVCs and radically change the country's position in existing chains. The communications platforms developed in Foresight studies could be used to discuss the problems of GVCs with key actors: companies in the real sector of the economy, regional clusters, higher education institutions, research institutions, technology platforms, business associations, government authorities, and other interested parties.

An important stage of developing a comprehensive long-term strategy to embed Russia in GVCs is identifying so-called 'windows of opportunity', which are the most promising from the perspective of fruitful participation and of achieving a leading position in developmental economic areas. Of those examined in this article, GVCs in financial services, air travel, agriculture, and information and communication technologies all offer opportunities. However, efforts to integrate into existing (or even dying) GVCs with a high level of competition and stable group of major players (the automotive industry) would appear counterproductive.

The principles and methods used to identify the positions and roles of companies in GVCs are in many ways tied to the aims and objectives decided upon when developing Russia's Long-Term Science and Technology Development Forecast. Therefore, conceptual approaches to studying the interactions in global chains and innovative development trends are of particular value for research, both at a state level, taking into account the specific nature of the national innovation system, and at an institutional level, on the level of individual companies and firms.

The authors would like to express their gratitude to all those involved in the 'Organization for Economic Co-operation and Development (OECD) Analysis of Leading Areas of Research in the field of Science, Technology and Innovation and Development of Information and Analytical Systems for Collaboration with the OECD in Priority Areas of Science, Technology and Innovation Policy' project (code: 2015-14-573-0022-002) carried out by NRU HSE further to its obligations under Subsidy Agreement No. 14.602.21.0011 as part of the special federal programme 'Research and Development in Russian Priority SeT Development Areas in 2014-2020', including the students in the Faculty of World Economy and International Affairs at NRU HSE Yuliya Bodrova and Dmitriy Kalugin who took part in the industry analysis.

\section{References}

Belousov A. (2013) Loukost. Saga. Zatmenie [Low-Cost. Saga. Eclipse]. Ekspert [Expert], 04.03.2013. Available at: http://expert.ru/ural/2013/09/loukost-saga-zatmenie/, accessed 24.07.2015 (in Russian).

Belousov A. (2014) Polet subsidii [Flight of the subsidy]. Ekspert [Expert], 07.07.2014. Available at: http://expert.ru/ ural/2014/28/polet-subsidij_1/, accessed 24.07.2015 (in Russian).

Bessarabova M., Sologub A. (2015) Rossiiskie aviakompanii snizhayut tseny [Russian Airlines Cut Prices]. Delovoi Peterburg, 03.03.2015. Available at: http://www.dp.ru/a/2015/03/03/Prizemlenie_cen/, accessed 24.07.2015 (in Russian).

Chulok A. (2009) Prognoz perspektiv nauchno-tekhnologicheskogo razvitiya klyuchevykh sektorov rossiiskoi ekonomiki: budushchie zadachi [Forecast of S\&T Development Prospects of the Key Economy Sectors in Russia: Future Tasks]. Foresight-Russia, vol. 3, no 3, pp. 30-36 (in Russian).

Cooke P.N. (2001) Regional innovation systems, clusters, and the knowledge economy, Oxford: Oxford University Press.

De Backer K., Miroudot S. (2014) Mapping Global Value Chains (Working Paper Series no 1677), Frankfurt am Main: European Central Bank.

DiLorenzo T.J. (1996) The myth of natural monopoly. The Review of Austrian Economics, vol. 9, pp. 43-58. DOI:10.1007/BF01103329.

Ernst D., Kim L. (2002) Global production networks, knowledge diffusion, and local capability formation. Research Policy, vol. 31, pp. 1417-1429. DOI:10.1016/s0048-7333(02)00072-0.

Etzkowitz H., Leydesdorff L. (2000) The Dynamics of Innovation: From National Systems and "Mode 2" to a Triple Helix of University-Industry-Government Relations. Research Policy, vol. 29, pp. 109-123.

EU Newsroom (2015) EU sanctions against Russia over Ukraine crisis. Available at: http://europa.eu/newsroom/ highlights/special-coverage/eu_sanctions/index_en.htm, accessed 31.12.2015. 
Federal Customs Service (2015) Tovarnaya struktura eksporta Rossiiskoi Federatsii so vsemi stranami: yanvar'-dekabr' $2014 \mathrm{~g}$. [Structure of Russian commodities exports to all countries in January-December 2014]. Available at: http://customs.ru/index2.php?option=com_content\&view=article\&id=20490\&Itemid=1978, accessed 24.07.2015 (in Russian).

Gereffi G. (1999) International trade and industrial upgrading in the apparel commodity chain. Journal of International Economics, vol. 48, pp. 37-70. DOI:10.1016/S0022-1996(98)00075-0.

Gereffi G., Humphrey J., Kaplinsky R., Sturgeon T.J. (2001) Introduction: Globalisation, Value Chains and Development, Brighton: Institute of Development Studies.

Gereffi G., Humphrey J., Sturgeon T. (2005) The governance of global value chains. Review of International Political Economy, vol. 12, no 1, pp. 78-104. DOI:10.1080/09692290500049805.

Gereffi G., Kaplinsky R. (2001) The value of value chains: Spreading the gains from globalization, Brighton: Institute of Development Studies.

Gibbon P. (2001) Upgrading Primary Production: A Global Commodity Chain Approach. World Development, vol. 29, no 2, pp. 345-363. DOI: 10.1016/S0305-750X(00)00093-0.

Gibbon P. (2003) The African Growth and Opportunity Act and the Global Commodity Chain for Clothing. World Development (Part special issue: Links between poverty and environment degradation in Latin America), vol. 31, no 11, pp. 1809-1827. DOI: 10.1016/j.worlddev.2003.06.002.

Gokhberg L. (ed.) (2014) Prognoz nauchno-tekhnologicheskogo razvitiya Rossii: 2030 [Russia’s Long-term S\&T Foresight 2030], Moscow: Russian Ministry of Science and Education, HSE (in Russian).

Gurría A. (2015) "21 for 21": A Proposal for Consolidation and Further Transformation of the OECD, Paris: OECD. Available at: http://www.oecd.org/about/secretary-general/21-for-21-A-Proposal-for-Consolidation-and-FurtherTransformation-of-the-OECD.pdf, accessed 08.12.2015.

HSE (2016) Global'nye tekhnologicheskie trendy [Global Technology Trends] (ed. L. Gokhberg), Moscow: HSE (in Russian).

Humphrey J., Lecler Y., Salerno M.S. (eds.) (2000) Global strategies and local realities: The auto industry in emerging markets, New York; Basingstoke: Macmillan Press; St. Martin's Press.

Humphrey J., Schmitz H. (2002) How does insertion in global value chains affect upgrading in industrial clusters? Regional Studies, vol. 36, pp. 1017-1027. DOI:10.1080/0034340022000022198.

Kaplinsky R. (2000) Spreading the gains from globalisation: What can be learned from value chain analysis? Journal of Development Studies, vol. 37, no 2, pp. 117-146.

Kaplinsky R. (2004) Spreading the Gains from Globalization: What Can Be Learned from Value-Chain Analysis? Problems of Economic Transition, vol. 47, no 2, pp. 74-115.

Kaplinsky R. (2013) Global Value Chains: Where They Came From, Where They Are Going and Why This Is Important (IKD Working Paper no 68), Milton Keynes, UK: The Open University.

Ken Research (2014) Russia seed industry outlook to 2018 - Cost-effective non-hybrid seeds to drive market growth, Gurgaon: Ken Research.

Kukushkin M. (2015) Nichego lichnogo [Nothing Personal]. RBK+. Vozdushnyi transport [RBC+. Air Transport], no 1, 18.05.2015. Available at: http://www.rbcplus.ru/news/5555b15e7a8aa901410298bf, accessed 24.07.2015 (in Russian).

Lundvall B.-A., Jurowetzki R., Lema R. (2015) Combining the Global Value Chain and the Innovation System perspectives (Paper presented at the DRUID Academy conference in Rebild, Aalborg, Denmark, January 21-23, 2015). Available at: http://druid8.sit.aau.dk/acc_papers/p8ym61f17dacl4e0v3afdaitvntv.pdf, accessed 12.11.2015.

Malerba F., Nelson R. (2011) Learning and catching up in different sectoral systems: Evidence from six industries. Industrial and Corporate Change, vol. 20, no 6, pp. 1645-1675. DOI:10.1093/icc/dtr062.

Meshkova T., Moiseichev E. (2015) Mirovye tendentsii razvitiya global'nykh tsepochek sozdaniya dobavlennoi stoimosti i uchastie v nikh Rossii [Global Value Chains: World Trends and the Russia's Involvement]. Vestnik Finansovogo Universiteta [Bulletin of the Financial University], no 1(85), pp. 83-97 (in Russian).

Milberg W., Winkler D. (2011) Economic and social upgrading in global production networks: Problems of theory and measurement. International Labour Review, vol. 150, no 3-4, pp. 341-365.

Morrison, A., Pietrobelli, C., Rabellotti, R. (2008) Global Value Chains and Technological Capabilities: A Framework to Study Learning and Innovation in Developing Countries. Oxford Development Studies, vol. 36, no 1, pp. 39-58. DOI: $10.1080 / 13600810701848144$.

Novaya Gazeta (2010) Ushla na bazu [Gone to Base]. Novaya Gazeta, 27.09.2010. Available at: http://www. novayagazeta.ru/politics/1563.html, accessed 23.07.2015 (in Russian).

OECD (2010) Global Value Chains: Russian Federation (A descriptive note), Paris: OECD. Available at: http://www. oecd.org/sti/ind/GVCs\%20-\%20RUSSIAN\%20FEDERATION.pdf, accessed 17.10.2015.

OECD (2013) Interconnected Economies: Benefiting from Global Value Chains, Paris: OECD.

OECD (2015a) Input-Output Tables, Available at: http://www.oecd.org/sti/ind/input-outputtables.htm, accessed 03.12 .2015

OECD (2015b) Digital Economy Outlook 2015, Paris: OECD.

OECD, World Bank (2015) Inclusive Global Value Chains: Policy options in trade and complementary areas for GVC Integration by small and medium enterprises and low-income developing countries (Report prepared for submission to G20 Trade Ministers Meeting, Istanbul, Turkey, 6 October 2015), Paris: OECD, World Bank Group.

OECD, WTO (2013) OECD-WTO: Statistics on Trade in Value Added, Paris: OECD.

OECD, WTO, UNCTAD (2013) Implications of Global Value Chains for Trade, Investment, Development and Jobs, Paris: OECD, WTO, UNCTAD.

OECD, WTO, World Bank Group (2014) Global Value Chains: Challenges, Opportunities, and Implications for Policy (Report prepared for submission to the G20 Trade Ministers Meeting, Sydney, Australia), Paris: OECD, WTO, World Bank Group. 
Pietrobelli C., Rabellotti R. (2011) Global Value Chains Meet Innovation Systems: Are There Learning Opportunities for Developing Countries? World Development, vol. 39, no 7, pp. 1261-1269. DOI: 10.1016/j.worlddev.2010.05.013.

RBC (2015) Rossiiskie aviakompanii vpervye obognali RZhD po chislu passazhirov [Airlines in Russia for the first time ahead of Railways in terms of passengers]. Available at: http://www.rbc.ru/rbcfreenews/55b7a50a9a79478b69ec4 526, accessed 29.07.2015 (in Russian).

RBC.research (2015) Grazhdanskaya aviatsiya v Rossii: regulyarnye soobshcheniya 2014 [Civil Aviation in Russia: Regular Reports 2014], Moscow: RBK Marketingovye Issledovaniya [RBC Marketing Research] (in Russian).

RZD-Partner (2015) Rynok gruzovykh aviatsionnykh perevozok $v$ Rossii rastet [Market cargo air transportation in Russia is growing]. Available at: http://www.rzd-partner.ru/news/aviaperevozki/rynok-gruzovykh-aviatsionnykhperevozok-v-rossii-rastet/, accessed 29.07.2015 (in Russian).

Sturgeon T.J. (2001) How Do We Define Value Chains and Production Networks? IDS Bulletin, vol. 32, no 3, pp. 9-18. DOI: 10.1111/j.1759-5436.2001.mp32003002.x.

Timmer M., Erumban A.A., Gouma R., Los B., Temurshoev U., de Vries G.J., Arto I. (2012) The World Input-Output database (WIOD): Contents, sources and methods, Brussels: European Commission. Available at: http://www.wiod. org/publications/source_docs/WIOD_sources.pdf, accessed 05.11.2015.

U.S. Department of State (2014) Russia and Ukraine Sanctions, Department of the Treasury. Available at: http://www. state.gov/e/eb/tfs/spi/ukrainerussia/index.htm, accessed: 31.12.2014.

Vasigh B., Erfani G., Sherman B. (2015) Airport Performance and Ownership Structure: Evidence from the United Kingdom, United States, and Latin America. Journal of Aviation Technology \& Engineering, vol. 4, no 2, pp. 40-49. DOI: $10.7771 / 2159-6670.1100$.

Vasigh B., Fleming K., Tacker T. (2013) Introduction to Air Transport Economics: From Theory to Applications, Aldershot: Ashgate Publishing.

Wood A. (2001) Value Chains: An Economist's Perspective. IDS Bulletin, vol. 32, no 3, pp. 41-45. DOI: 10.1111/ j.1759-5436.2001.mp32003005.x.

Zhang Y., Round D.K. (2011) Price wars and price collusion in China's airline markets. International Journal of Industrial Organization, vol. 29, no 4, pp. 361-372. DOI: 10.1016/j.ijindorg.2010.07.005. 